Received

10 Desember 2018
Revisied

20 Februari 2019
Acceptep

16 Juni 2019

\title{
GAMBARAN INISIASI SEKS PRA NIKAH PADA REMAJA
}

\author{
Laily Mualifah $^{1}$, Budi Punjastuti ${ }^{2}$ \\ ${ }^{1}$ Dosen Prodi DIII Keperawatan Poltekkes Karya Husada Yogyakarta \\ Email: lailymualifah84@gmail.com \\ ${ }^{2}$ Dosen Prodi DIII Keperawatan Poltekkes Karya Husada Yogyakarta \\ Email: budipunjastuti@yahoo.com
}

\begin{abstract}
ABSTRAK
Latar Belakang: Seks pra nikah di Kota Yogyakarta telah dilakukan survey sejak tahun 1994 yang difokuskan pada masalah di kalangan mahasiswa, dan tahun 1999 diperluas di kalangan remaja. Hasil survey tersebut diperoleh 8 dari 10 remaja pernah melakukan hubungan seks pra nikah. Inisiasi seksual dini merupakan isu kesehatan dan sosial yang penting. Studi yang sudah dilakukan menunjukkan bahwa sebagian besar yang sudah seksual ada keinginan menunda lebih lama dalam melakukan hubungan seksual. Dampaknya, remaja yang melakukan seksual dini lebih banyak. Tujuan: Mengetahui gambaran inisiasi seks pra nikah pada remaja. Metode: Penelitian ini menggunakan pendekatan deskriptif. Penelitian dilakukan di Badran Kelurahan Bumijo Jetis Yogyakarta. Jumlah responden sebanyak 34 responden. Instrument yang digunakan menggunakan kuesioner yang dimodifikasi. Hasil: Hasil penelitian ini menunjukkan bahwa inisiasi seks pra nikah yang sudah dilakukan oleh responden adalah dari 34 responden, pernah berpegangan tangan sebesar (55.8\%), berpelukan sebesar (35.29\%), kencan khusus berduaan sebesar (14.70\%), cium pipi sebanyak (14.70\%) serta cium bibir sebanyak (5.8\%). Kesimpulan: Gambaran inisiasi seks pra nikah yang dilakukan remaja adalah berpegangan tangan, berpelukan, kencan khusus berduaan, cium pipi, cium bibir.
\end{abstract}

Kata Kunci: inisiasi seks pra nikah pada remaja

\section{ABSTRACT}

Background: Pre-marital sex in the city of Yogyakarta has been conducted a survey since 1994 which focused on problems among students, and in 1999 it was expanded among adolescents. The survey results obtained by 8 out of 10 adolescents have had premarital sex. Early sexual initiation is an important health and social issue. Studies that have been conducted show that the majority of those who are already sexual desire to delay longer in having sexual relations. The impact, more adolescents who have early sex. Objective: Knowing the picture of premarital sex initiation in adolescents.Method: This research uses a descriptive approach. The study was conducted at Badran Urban Village, Bumijo Jetis, Yogyakarta. The number of respondents was 
Jurnal Kesehatan Karya Husada, No 7 Vol 2 Tahun 2019

PISSN 2337649X/EISSN 2655-8874

Laily Mualifah, Budi Punjastuti “Gambaran Inisiasi Seks Pra Nikah Pada Remaja” (hal 208-214)

34 respondents. The instrument used was a modified questionnaire. Results: The results of this study indicate that premarital sex initiation that has been carried out by respondents is from 34 respondents, had held hands by (55.8\%), hugged by (35.29\%), special dates together for (14.70\%), kissed cheeks as much (14.70\%) and kiss as much as lip (5.8\%). Conclusion: The description of premarital sex initiation by teenagers is holding hands, hugging, special dates together, kiss on the cheeks, kiss the lips

Keywords: initiation of premarital sex in adolescents

\section{PENDAHULUAN}

Perrmasalahan inisiasi seks remaja merupakan permasalahan umum yang semakin marak. Usia remaja merupakan usia yang secara biologis sudah matang, namun bila melakukan perilaku seksual dapat mengakibatkan permasalahan jangka panjang (Maimunah, Kunci, Seksual, \& Keluarga, 2015). Inisiasi seks merupakan bagian dari kesehatan reproduksi yang saat ini mendapatkan perhatian khusus secara global sejak diangkatnya issue dalam Konferensi Internasional tentang Kependudukan dan pembangunan (International Conference on Population and Development, ICPD di Kairo Mesir oada tahun 1994.

Hasil survey penduduk antar sensus 2015 menunjukkan bahwa penduduk usia 15-24 tahun mencapai 42.061,2 juta atau sebesar $16,5 \%$ dari total penduduk Indonesia. Hasil proyeksi penduduk menunjukkan bahwa jumlah penduduk usia remaja ini akan mengalami peningkatan hingga tahun 2030 dan kemudian menurun sesudahnya. (Kusumaryani, 2017). Secara umum, remaja laki - laki yang menyatakan pernah melakukan hubungan seks pra nikah lebih banyak dibandingkan remaja perempuan. Dibandingkan tahun 2007 bahkan mengalami peningkatan prosentase. Seks pra nikah yang diawali dengan inisiasi seks pada remaja beresiko terhadap terjadinya kehamilan di usia muda dan penularan penyakit seksual. Kehamilan remaja yang tidak diinginkan pada remaja perempuan berdampak aborsi dan pernikahan dini serta berdampak pada masa depan remaja, janin dan keluarga remaja (Kusumaryani, 2017). Masa remaja merupakan dimulainya perkembangan seksual yang ditandai dengan berbagai perubahan fisik dan hormonal sejak pubertas. Pada masa ini remaja menghadapi konsekuensi sosial dan psikologis yang besar. Rasa ingin mencoba - coba yang besar mulai muncul akibat adanya berbagai perubahan tersebut (Suwarni \& Selviana, 2015).

Survei Litbang Kesehatan bekerjasama dengan Unesco menunjukan sebanyak $5,6 \%$ remaja Indonesia sudah melakukan seks pranikah. Survei skrining adiksi pornografi yang dilakukan di DKI Jakarta dan Pandeglang menunjukkan sebanya 96,7\% telah terpapar pornografi dan $3,7 \%$ mengalami adiksi pornografi (BKKBN, 2018). Perilaku seksual merupakan tingkah laku yang didorong oleh hasrat seksual yang dapat dilakukan oleh lawan jenis maupun sesama jenis. Bentuk bentuk tingkah laku seksual Page 209| 
Jurnal Kesehatan Karya Husada, No 7 Vol 2 Tahun 2019

PISSN 2337649X/EISSN 2655-8874

Laily Mualifah, Budi Punjastuti “Gambaran Inisiasi Seks Pra Nikah Pada Remaja” (hal 208-214)

bermacam - macam, diantaranya berciuman, necking, meraba bagian sensitive, saling menggesekkan bagian - bagian sensiitif hingga berhubungan seksual (Tanib, Kalesaran, \& Ratag, 2016). Inisiasi seksual dini merupakan isu kesehatan dan sosial yang penting. Berdasarkan penelitian Suwarni tahun 2015 bahwa sebagian besar remaja yang sudah berpengalaman seksual menyatakan ada keinginan untuk menunda lebih lama dalam melakukan hubungan seksual. Hal ini berdampak remaja yang melakukan hubungan seksual dini lebih banyak mengalami kehamilan yang tidak diinginkan, infekksi menular seksual (Suwarni \& Selviana, 2015). Perilaku seksual saat ini di Indonesia sudah mengkhawatirkan. Hasil survey BKKBN tahun 2010 bahwa seks pranikah yang dilakukan remaja di Yogyakarta, sekitar $37 \%$ dari 1160 mahasiswa mengaku mengalami kehamilan sebelum menikah. Berdasarkan pentingnya issue seks pra nikah di atas, maka penting dilakukan penelitian yang berkaitan dengan gambaran inisisasi seks pra nikah. Tujuan dari penelitian ini adalah mengetahui gambaran inisiasi seks pra nikah pada remaja di wilayah Badran Bumijo Kecamatan Jetis Yogyakarta.

\section{METODE PENELITIAN}

Penelitian ini merupakan penelitian deskriptif yang bertujuan untuk mengetahui gambaran inisiasi seks pra nikah pada remaja. Penelitian dilakukan di Wilayah Badran Bumijo kecamatan Jetis dengan jumlah sampel sebanyak 34 responden. Inisiasi seks pra nikah pada remaja dalam penelitian ini adalah mencoba- coba perilaku seksual seperti berpegangan tangan, berpelukan, berciuman pipi, ciuman bibir, meraba daerah sensitive serta menggesek gesekkan daerah sensitive. Kuesioner penelitian ini merupakan modifikasi dari kuesioner penelitian Suwarni tahun 2015 (Suwarni \& Selviana, 2015).

\section{HASIL DAN PEMBAHASAN}

\section{HASIL PENELITIAN}

Responden dalam penelitian ini merupakan remaja berusia 12 tahun sampai dengan 18 tahun yang tinggal di wilayah Badran Kelurahan Bumijo kecamatan Jetis Yogyakarta. Responden yang memenuhi kriteria inklusi sebanyak 34. Responden berjenis kelamin laki - laki sebanyak $(29,4 \%)$ dan perempuan sebanyak $(70,6 \%)$. Berdasarkan hasil penelitian Suwarni (2015) jenis kelamin tidak 
mempengaruhi inisiasi seks pra nikah namun memiliki kecenderungan melakukan inisiasi seks pra nikah dibandingkan perempuan sebesar 1,256 kali. Hal ini terjadi karena adanya sifat asertif dan agresif pada laki laki daripada perempuan. Jenis kelamin laki - laki juga memiliki memiliki standar ganda. Adanya standar ganda ini yang berlaku di masyarakat secara langsung atau tidak langsung mendorong remaja lakilaki menjadi lebih permisif dalam perilaku seksual. Remaja laki- laki lebih diberikan kebebasan dalam perilaku seks daripada perempuan (Suwarni \& Selviana, 2015). Penelitian Yuliano (2010) di Jakarta mengenai perilaku seks pranikah remaja menunjukkan bahwa remaja laki - laki cenderung bersikap menerima / permisif terhadap perilaku seks pranikah (Yulianto, 2010). Responden dengan tingkat pendidikan orang tua paling banyak adalah SLTA sebanyak (55.9\%) untuk ayah dan untuk ibu sebanyak (50\%). Status pernikahan orang tua dalam penelitian ini, responden yang orang tuanya menikah dan tinggal bersama sebanyak $(67,6 \%)$. Kebersamaan orang tua dan tinggal satu rumah diharapkan dapat memantau segala aktivitas anak. Orang tua mempunyai peran penting dalam dalam proses sosialisasi anak. Orang tua merupakan media belajar bagi anak mulai dari nilai - nilai dan sikap yang terdapat dan dianut masyarakat. Orang - orang yang tidak memiliki hubungan harmonis dengan orang tuanya dimasa kecil maka kemungkinan ketika besar akan sering melanggar normanorma masyarakat (Banun \& Setyorogo, 2013). Status perkawinan cerai/ janda/duda memiliki persentase anak melakukan perilaku seksual beresiko $(55,6 \%)$. Dan seringnya orang tua bertengkar serta perceraian orang tua dapat mengalihkan kejenuhan remaja dengan melakukan perilaku seksual (Sekkarini, 2011). Usia menarche dan mimpi basah pada penelitian ini sebanyak (50\%) pada usia 12 tahun dan paling rendah pada usia 10 tahun sebanyak (8.8\%). Peristiwa menarche dan mimpi basah akan dialami oleh setiap pra remaja. Peristiwa ini merupakan tanda seseorang mulai memasuki masa pubertas. Terjadinya peristiwa ini menandakan bahwa manusia mulai berfungsinya system reproduksi. Peristiwa inipun akan mendorong keinginan seksual seseorang. Perkembangan seksual dimulai pada masa remaja melalui perubahan fisik dan hormonal sejak pubertas. Pada masa ini, 
rasa ingin tahu dan coba - coba terkait masalah seksual mulai muncul karena perubahan biologis dan fisik Kepemilikan pacar dari responden, memiliki pacar sebanyak $(61,8 \%)$ dan umur saat memliki pacar sebanyak 12 - 13 tahun sebanyak $(41,11 \%)$ dan sebanyak $(20,58 \%)$ sudah memiliki pacar mulai umur $9-11$ tahun. Memiliki pacar merupakan salah satu faktor yang menyebabkan terjadinya perilaku seksual remaja walaupun termasuk dalam perilaku seksual yang tidak beresiko. Hal ini sesuai dengan penelitian Banun (2013) bahwa responden memiliki perilaku tidak beresiko seperti berpacaran sebanyak $(94,3 \%)$. Bila dilihat dari hasil penelitian peneliti, dan didukung penelitian yang lainnya bahwa awal mula dimulainya inisiasi seks pra nikah pada remaja dapat dilihat dari besarnya responden yang memiliki pacar. Inisiasi seks pra nikah dalam penelitian ini adalah pegangan tangan, berpelukan, kencan khusus berduaan, cium pipi dan cium bibir serta meraba daerah sensitive.Jumlah responden yang paling banyak melakukan pegangan tangan $(55,8 \%)$, berpelukan $(35,29 \%)$, kencan khusus berduaan $(14,70 \%)$, cium pipi $(14,70 \%)$ dan cium bibir (5,8\%). Dari 34 responden, belum ada yang melakukan inisiasi seks meraba daerah sensitive. Hal ini sesuai penelitian yang dilakukan Banun (2012) bahwa proporsi responden yang beresiko perilaku seksual pranikah adalah berciuman bibir (53\%), meraba raba dada $(18,4 \%)$, meraba kelamin $(5,7 \%)$, hubungan seksual (6,5\%). Sedangkan perilaku seksual tidak beresiko terdiri dari berpacaran $(90,8 \%)$, berangkulan $(80,1 \%)$, berpelukan $(69,3 \%)$ dan berciuman pipi (73,9\%). Permasalahan inisiasi seks pranikah semakin meningkat. Hal ini bisa disebabkan karena masa remaja yang sangat mudah terpengaruh dengan lingkungan sekitar. Perkembangan tekhnologi yang semakin pesat juga menjadikan remaja bebas dalam mengakses berbagai informasi. Saat usia remaja, perasaan untuk diterima pada kelompoknya menjadi hal yang paling penting. Menurut penelitian Azinar (2013) bahwa perilaku teman sebaya memiliki hubungan dengan perilaku beresiko terhadap kehamilan yang tidak diinginkan. Remaja yang mempunya teman berperilaku beresiko terhadap kehamilan yang tidak diinginkan cenderung akan mengadopsi perilaku 
tersebut (Azinar, 2008) Semakin canggihnya tekhnologi dan kebebasan remaja dalam mengakses media juga menyebabkan remaja melakukan inisiasi seks pranikah. Di lingkungan saat ini remaja lebih tertarik dengan materi seks yang berbau porno dibandingkan dengan materi seks yang dikemas dalam bentuk pendidikan kesehatan.Hal ini memang berhubungan dengan masa remaja yang merupakan masa transisi.

\section{SIMPULAN DAN SARAN}

\section{DAFTAR PUSTAKA}

Azinar, M. (2008). Perilaku Seksual Pranikah Berisiko Terhadap Kehamilan Tidak Diinginkan. Kesehatan Masyarakat, 8(2),153160.https://doi.org/10. 15294/kemas.v8i2.2639

Banun, F., \& Setyorogo, S. (2013). Faktor-faktor yang berhubungan dengan perilaku seksual pranikah pada mahasiswa semester v Stikes $\mathrm{x}$ Jakarta Timur 2012. Jurnal Ilmiah Kesehatan, 5(1), 1219.

\section{SIMPULAN}

Berdasarkan penelitian ini dapat disimpulkan bahwa inisiasi seks atau mencoba coba seks pada remaja yang dilakukan responden yang paling banyak melakukan pegangan tangan $(55,8 \%)$, berpelukan $(35,29 \%)$, kencan khusus berduaan $(14,70 \%)$, cium pipi $(14,70 \%)$ dan cium bibir $(5,8 \%)$. Dari seluruh responden, belum ada yang melakukan inisiasi seks meraba daerah sensitive.

BKKBN. (2018). 56\% Remaja Telah melakukan Seks Pranikah; (Surat kabar Suara Pembarauan 28 Agustus 2018. Retrieved from http://sdki.bkkbn.go.id/?langha $\mathrm{t}=$ newsdetail\&id=9\&typeews

Kusumaryani, M. (2017). Brief notes : Prioritaskan kesehatan reproduksi remaja untuk menikmati bonus demografi. Lembaga Demografi FEB UI, 1-6. Retrieved fro http://ldfebui.org/wpcontent/u ploads/2017/08/BN-02017.pdf

Maimunah, S., Kunci, K., Seksual, P., \& Keluarga, F. (2015). 
Jurnal Kesehatan Karya Husada, No 7 Vol 2 Tahun 2019

PISSN 2337649X/EISSN 2655-8874

Laily Mualifah, Budi Punjastuti “Gambaran Inisiasi Seks Pra Nikah Pada Remaja” (hal 208-214)

SEMINAR PSIKOLOGI \&

KEMANUSIAAN Pengaruh

Faktor Keluarga terhadap

Perilaku Seksual Remaja. 978-

979.

Sekkarini. (2011). Faktor - faktor yang Berhubungan dengan Perilaku Seksual Remaja di SMK Kesehatan di Kabupaten Bogor. Universitas Indonesia.

Suwarni, L., \& Selviana, S. (2015). Inisiasi Seks Pranikah Remaja Dan Faktor Yang Mempengaruhi. Jurnal Kesehatan Masyarakat, 10(2), 169.https://doi.org/10.15294/k emas.v10i2.3378

Tanib, A. I., Kalesaran, A. F. C., \& Ratag, B. T. (2016). FaktorFaktor Yang Berhubungan Dengan Perilaku Seksual Pranikah Pada Remaja Di Kelurahan Lawangirung Kecamatan Wenang Kota Manado. Fakultas Kesehatan Masyarakat Universitas Sam Ratulangi, 1-9.

Yulianto. (2010). No TitleGambaran Sikap Siswa SMP terhadap Perilaku Seksual Pranikah (Penelitian dilakukan di
SMPN 159 Jakarta). Jurnal

Psikologi, 8(2): 46-58 